\title{
Odpowiedzialność biznesu. Teoria i praktyka
}

Prof. nadzw. dr hab. Sylwia Sysko-Romańczuk | Szkoła Główna Handlowa | ssysko@sgh.waw.pl Dr Paulina Roszkowska | Szkoła Główna Handlowa | proszkowska@gmail.com Agnieszka Niedźwiecka | Telekomunikacja Polska SA | niedzwiecka.agnieszka@gmail.com

\section{Abstrakt}

Cel

Celem artykułu jest przedstawienie koncepcji odpowiedzialności biznesu i jej poziomów w perspektywie celu nadrzędnego firmy, jakim jest przyczynianie się jej do budowania dobra wspólnego.

\section{Metodologia}

W metodyce badawczej wykorzystano dyskusję literaturową, przedstawiono wyniki badań i rezultaty badawcze techniki grup fokusowych przeprowadzonej w trakcie II konferencji naukowej Czas na rozwój. Człowiek i biznes w społeczeństwie obywatelskim.

\section{Wnioski}

Głównym zadaniem przedsiębiorstwa jest dostarczanie towarów i usług przydatnych dla społeczeństwa, generowanie wartości dodanej, dzielenie tego nowego dobrobytu wśród swoich akcjonariuszy, pracowników, społeczność, w której firma się rozwija oraz kapitalizowanie firmy, by zagwarantować jej przyszłość. Towary i usługi dostarczane przez firmę muszą spełniać kryterium wysokiej jakości i odpowiedniej ceny, a także muszą być przydatne dla społeczeństwa. Społecznie odpowiedzialna firma nie może bazować na ludzkich słabościach. Generowanie wartości dodanej oznacza jej zdobywanie bez wchodzenia w układy monopolistyczne lub korzystania ze specjalnych przywilejów. Firma jest główną instytucją redystrybucji bogactwa ekonomicznego i dzieli je między swoich interesariuszy w odpo- 
wiednich formach. Równocześnie firma musi zapewnić sobie i swoim właścicielom przyszłość, inwestując w nowe technologie i aktywa. Kiedy firma spełni wszystkie swoje podstawowe obowiązki, możemy stwierdzić, że środki, które przeznacza na cele społeczne, są „prawdziwe”, a nie „wykradzione” klientom, pracownikom, dostawcom, społeczeństwu lub przyszłym pokoleniom. Nie można dyskutować o odpowiedzialności firmy, jeśli nie spełnia ona swoich zasadniczych obowiązków.

\section{Oryginalność}

O oryginalności opracowania świadczy teoretyczne (dla badaczy) i praktyczne (dla menedżerów) przedstawienie koncepcji odpowiedzialności biznesu.

\section{JEL: M14}

\section{Wprowadzenie}

Kryzys finansowy 2008 r. i jego skutki społeczno-gospodarcze wywołały napięcie oraz skłoniły do wzięcia pod lupę decyzji menedżerów instytucji i przedsiębiorstw. Jedni analitycy obarczają odpowiedzialnością konkretne osoby, np. Alana Greenspana, szefa FEDu, inni - grupy polityków, bankierów, jeszcze inni - niewłaściwe regulacje czy działalność przedsiębiorstw. Komu można przypisać odpowiedzialność i jaki jest jej zakres? Nie wszyscy są tak samo odpowiedzialni. Jaka jest różnica między odpowiedzialnością osoby - decydenta a odpowiedzialnością podmiotu - osoby prawnej? Czy szeroko promowana w Europie idea społecznej odpowiedzialności biznesu, zwłaszcza koncepcji shared value czy blended value, jest sprzeciwem wobec zjawiska uspołecznienia strat i prywatyzacji zysków ${ }^{1}$ ?

Dość powszechne jest zjawisko, że rządy, działacze społeczni i media to grupy interesów, które wyspecjalizowały się w rozliczaniu firm ze społecznych konsekwencji ich działalności. Nie ma wątpliwości, że pojęcie społecznej odpowiedzialności w biznesie zrobiło wiele zamieszania (Fontrodona 2006: 42-45). Sama koncepcja jednak nie jest ani przejściową modą, ani rewolucją. W Stanach Zjednoczonych (generalnie w świecie anglosaskim) preferuje się mówienie o etyce biznesu, zrównoważonym rozwoju (sustainability), podczas gdy pojęcie społecznej odpowiedzialności biznesu jest bardziej popularne w Europie. W USA traktuje się ją jako identyfikację antybiznesowych praktyk potwierdzonych przez tych, którzy są poza systemem (urzędy, instytuty). Udowodniono, że istnieje silna korelacja dodatnia między zaangażowaniem w praktyki społecznej odpowiedzialności biznesu a ubezpieczeniem reputacji firmy na wypadek negatyw-

\footnotetext{
Szef KNF Andrzej Jakubiak zaapelował 4 listopada 2011 r. o politykę ostrożnej dywidendy do banków i towarzystw ubezpieczeniowych oraz funduszy emerytalnych, np. PKO BP ma wypłacić za 2011 rok około 2,5 mld zł dywidendy; PZU chce wypłacić pomiędzy 50 a 100\%. Ponadto kurs akcji KGHM szaleje, a inwestorów czeka jeszcze dywidenda.
} 
nych skutków jej działań w przyszłości (Minor 2010: 1-27). Z kolei etykę biznesu postrzega się jako narzędzie, które pomaga doskonalić sposób działania biznesu. W Europie etyka biznesu nie jest dobrze odbierana, ponieważ charakteryzuje się pewnym moralizatorskim tonem. Znacznie łatwiej przyjmuje się społeczną odpowiedzialność biznesu. W każdym razie firmy „budzą się”, a menedżerowie uznają fakt, że podejmując decyzje, muszą wziąć pod uwagę nowe kryteria, które są czymś więcej niż narażaniem się na dodatkowe obowiązki lub dobry uczynek, że mogą one być dla firmy źródłem szans, innowacji i przewagi konkurencyjnej.

\section{| Odpowiedzialność biznesu - rozważania teoretyczne}

Wiedza o tym, czym jest firma i jaka jest jej misja, powoduje, że zarządzanie nią jest bardziej racjonalne (Sysko-Romańczuk 2011: 187-196) i odpowiedzialne. Zgodnie z definicją (Valero, y Lucas 1999) firma to grupa ludzi, która prowadzi handlową, produkcyjną, logistyczną i finansową działalność, realizując trzy podstawowe cele: dostarczanie społeczeństwu użytecznego produktu lub usługi; tworzenie ekonomicznej wartości dodanej; zapewnienie firmie ciągłości działania w przyszłości. Firma jest więc społecznością ludzi, współpracujących, by osiągnąć wspólny cel. Każdy z uczestników dostarcza pewnych zasobów lub ich kombinacji - niektórzy kapitału, niektórzy umiejętności menadżerskich, a niektórzy swojej pracy, a w zamian za to otrzymują odpowiednią do wkładu rekompensatę. Podstawowymi celami firmy są: dostarczanie produktów i usług dla dobra społeczeństwa; kreowanie ekonomicznej wartości dodanej i sprawiedliwe jej dystrybuowanie oraz zapewnienie ciągłości działania.

Odpowiedzialność firmy² wynika z faktu posiadania przez nią władzy i swobody działania. Duże korporacje mają olbrzymią władzę ekonomiczną ${ }^{3}$, technologiczną, polityczną, społecznokulturową i ekologiczną. Ekonomiczna władza firmy opiera się na jej kontroli nad finansami i zasobami, z kolei technologiczna jest wynikiem jej wpływu na rozwój nowych technologii i ich implementacji. Firmy czasami wykorzystują swoją władzę polityczną, aby zapewnić sobie korzystną regulację prawną. Siła marketingu i reklamy jest odbiciem dokonanych przez firmę zmian społeczno-kulturowych. W końcu firmy posiadają także zasoby, by chronić środowisko naturalne lub ignorować takie oczekiwania społeczne. W przypadku firm, tak jak w przypadku człowieka, władza implikuje odpowiedzialność (Mele 2009: 299-300). Podobnie jak w życiu osobistym najpierw jesteśmy odpowiedzialni przed swoją rodziną, potem firmą, branżą, społeczeństwem, tak w odpowiedzialności firmy też musi być zachowany porządek. Logika porządku

\footnotetext{
2 Z punktu widzenia moralno-etycznego przedsiębiorstwa nie są w stanie działać odpowiedzialnie; co najwyżej pracujący w nich ludzie, którzy podejmują decyzje. Nie można zatem przypisywać odpowiedzialności za działania całym przedsiębiorstwom, a jedynie ich pracownikom (najczęściej kadrze zarządzającej), którzy prowadzą własną politykę zarządzania. Dlatego trudno jest mówić o społecznej odpowiedzialności przedsiębiorstw, a winno się używać pojęcia „społeczna odpowiedzialność ludzi prowadzących działalność gospodarczą".

3 "Obywatelstwo" amerykańskiego koncernu General Electric jest dziś więcej warte niż czeskie czy węgierskie. Oznacza ono nie tylko bycie członkiem firmy, której roczne przychody są wyżzze niż PKB Węgier i Czech oraz dziesiątków innych państw. Często oznacza tez znacznie lepszą ochronę socjalną i bezpieczeństwo finansowe. Programy emerytalne, ubezpieczenia życiowe i medyczne, dotacje do studiów, refundacje kosztów wychowania dzieci, upusty przy zakupie wielu towarów i usług - to tylko część przywilejów (tzw. employee benefits), którymi kuszą dziś pracowników międzynarodowe korporacje. Niektóre, jak GE, na swoich stronach internetowych zawierają opis tych korzyści w części zatytułowanej właśnie „obywatelstwo".
} 
wymaga jednak zdefiniowania określonego końca, którym z perspektywy etycznej jest zmierzanie do dobra wspólnego (Sysko-Romańczuk 2007; Sysko-Romańczuk, Kruszyńska 2009: 52-59). Firma ma swój wkład w rozwój dobra wspólnego przez widoczne rezultaty końcowe swojej aktywności, a jej odpowiedzialność względem społeczeństwa odnosi się do zakresu tych rezultatów, którymi są: tworzenie efektywnie i uczciwie użytecznych produktów i usług; sprawiedliwe kreowanie ekonomicznej wartości dodanej i odpowiednie jej dystrybuowanie; tworzenie miejsc pracy, jej warunków i szans rozwoju pracowników w poszanowaniu ich ludzkiej godności i zgodnie z prawami człowieka; kształtowanie dobrych i koniecznych relacji opartych na współdziałaniu, współpracy, zaangażowaniu między firmą a jej istotnymi interesariuszami; dążenie do zapewnienia ciągłości działania firmy i jej stabilnego rozwoju; bycie jako firma odpowiedzialnym obywatelem (Wood, Logsdon 2002: 59-94).

Kwestia porządku odpowiedzialności wymaga jeszcze omówienia kwestii podmiotowej zagadnienia - nie tylko za co firma jest odpowiedzialna, ale także przed kim. Współcześnie funkcjonują dwie skrajne wizje firmy co do jej istoty, celu i odpowiedzialności. Pierwsza zakłada, że udziałowcy (shareholders) są właścicielami firmy, a menedżerowie są odpowiedzialni tylko przed udziałowcami. Celem firmy jest maksymalizowanie wartości dla udziałowców przy zachowaniu poszanowania prawa i przyzwyczajeń społeczności. W drugiej z kolei biznes to koordynowanie działań wielu grup, które pracują razem dla osiągnięcia wspólnego celu. Menedżerowie są odpowiedzialni przed różnymi grupami interesariuszy (stakeholders), które mają różny wkład w działalność biznesową firmy (Sysko-Romańczuk 2005). Cel firmy jest złożony. Chodzi o znalezienie rozwiązań kompromisowych w każdej decyzji, określanie priorytetów, które zmieniają się w zależności od sytuacji. Firmy zatem, podobnie jak jednostki, mogłyby zajmować się potrzebami wszystkich ludzi lub różnych grup społecznych, z którymi wchodzą w interakcje lub relacje współzależności. Fizycznie jednak jest to niemożliwe, ponadto często zdarza się, że interesy grup stoją w sprzeczności. Stąd idea odpowiedzialności firmy musi podlegać porządkowi określanemu jako współśrodkowe kręgi odpowiedzialności (Mele 2009: 326-332) zaprezentowane na rysunku 1.

\section{Rysunek 1 | Struktura poziomów odpowiedzialności firmy}

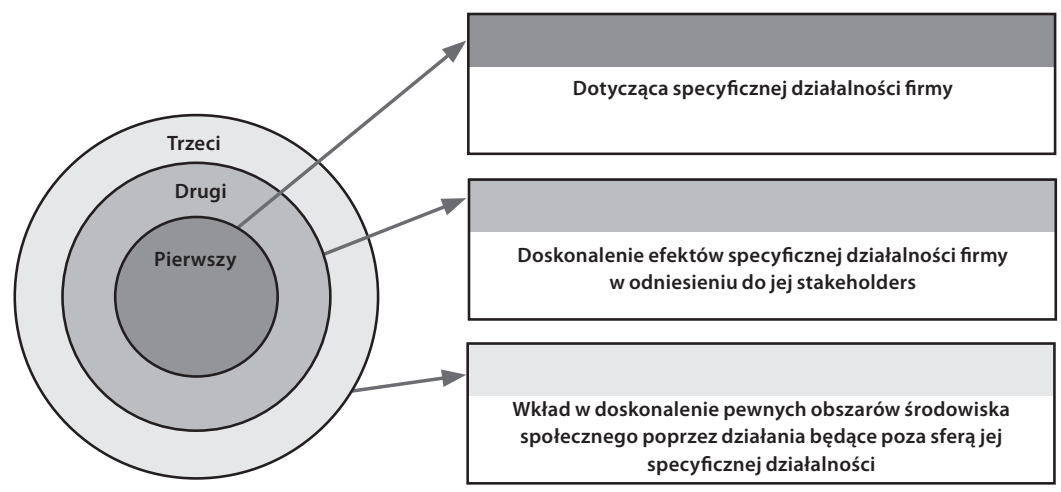

Źródło: opracowanie własne na podstawie: Mele (2009: 326-332); materiały do wykładu prof. J. Fontrodona, Business Ethics, III edycja AMP Warsaw IESE Business School. 
Możemy zatem mówić o trzech współśrodkowych kręgach odpowiedzialności wokół kadry zarządzającej firmy i jej relacji z interesariuszami: pierwszym, drugim i trzecim poziomie odpowiedzialności. Pierwszy wymaga, by być efektywnym (doskonałość biznesowa) tak, jak to tylko jest możliwe w obszarze prowadzonej działalności, osiągając rozsądny wzrost. Drugi obejmuje doskonalenie wpływu efektów specyficznej działalności firmy w odniesieniu do jej interesariuszy, a trzeci to działania, które podejmuje firma poza sferą swojej specyficznej działalności, aby doskonalić pewne aspekty środowiska społecznego.

Pierwszy poziom odpowiedzialności musi być analizowany z punktu widzenia podstawowych celów firmy, prezentowanych wcześniej, i środków używanych do ich osiągnięcia, czyli służyć społeczeństwu użytecznym produktem i/lub usługą na efektywnych i uczciwych warunkach; kreować bogactwo ekonomiczne (osiągnąć maksimum efektywności w działalności firmy), co oznacza generowanie korzystnych warunków ekonomicznych, by osiągać zysk na bieżąco, mając na uwadze ciągłe doskonalenie pozycji konkurencyjnej firmy, tak by mogła generować zysk w przyszłości. Zysk jest miarą efektywności wykorzystania zasobów firmy tylko z ekonomicznego punktu widzenia. Czym innym jest przychód ze sprzedaży na podstawowej działalności, a czym innym przychód z wynajmu środków produkcji. Czym innym jest wzrost udziału w rynku, a czym innym wartość akcji firmy na giełdzie. Pierwszą odpowiedzialnością firmy jest także zapewnić długookresową ciągłość działania i rozsądny wzrost, aby utrzymać i stworzyć nowe miejsca pracy. Największym wrogiem długookresowego utrzymania firmy jest pogoń za krótkookresowym zyskiem, kosztem długookresowej zyskowności. Wyprzedaż aktywów, obcięcie wydatków na rozwój kadry czy na prace R\&D poprawi rezultat finansowy natychmiast, ale w pewnych warunkach zagrozi przyszłemu rezultatowi. Odpowiedzialnością menedżerów jest utrzymanie równowagi pomiędzy krótko- i długookresową perspektywą rozwoju. Firma musi zagwarantować szacunek dla praw człowieka i wspieranie rozwoju ludzkiego pracowników. Praca ma umożliwić ludziom osobisty rozwój. Inaczej sama praca i jej rezultaty nie będą się doskonaliły. Szacunek dla środowiska (ekologia), rozsądne limity wykorzystania zasobów i nieniszczenie ich oraz przestrzeganie prawa i rzetelnie wypełnianie zapisów kontraktu (dostawcy, partnerzy, regulatorzy, klienci) i danych obietnic też mieszczą się na poziomie odpowiedzialności. W rezultacie firma musi zapewnić sprawiedliwe rozdzielanie wygenerowanego bogactwa (równowaga między generowaną EVA i dystrybuowaną EVA). Strukturę pierwszego poziomu odpowiedzialności prezentuje rysunek 2. 
Rysunek 2 | Struktura pierwszego poziomu odpowiedzialności firmy

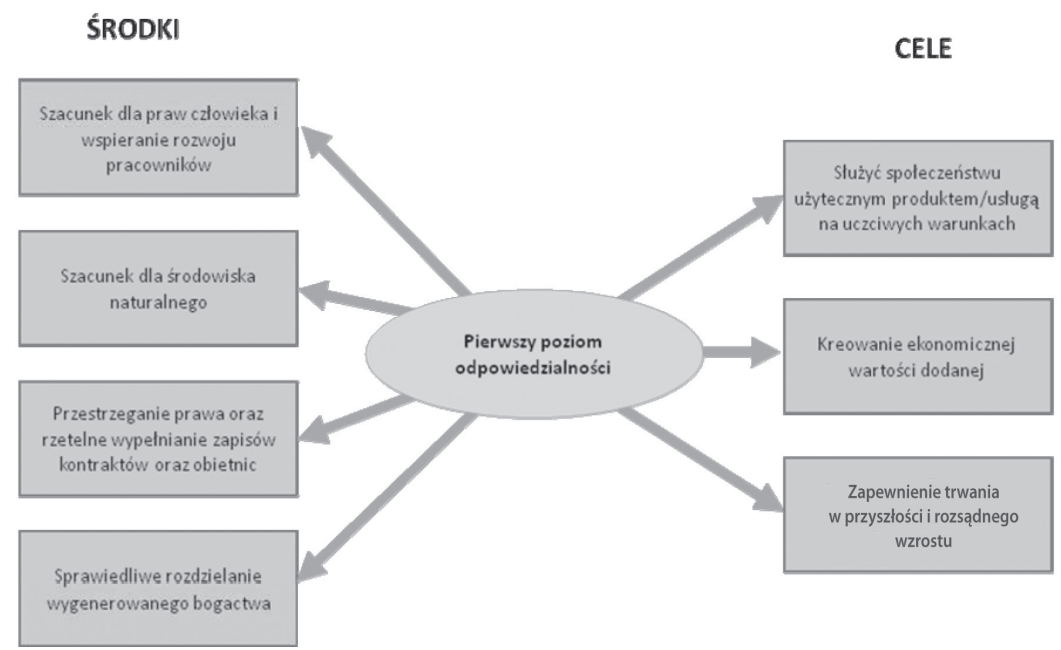

Źródło: opracowanie własne na podstawie: Mele (2009: 326-332); materiały do wykładu prof. J. Fontrodona, Business Ethics, III edycja AMP Warsaw IESE Business School.

Koncepcja drugiego poziomu odpowiedzialności jest raczej intuicyjna (rysunek 3). Firma musi dać priorytet tym, którzy są w bliższej relacji z nią samą: menedżerom, stałym pracownikom i zaangażowanym udziałowcom (to ci, którzy są nie tylko dawcami kapitału, ale także biorą aktywny udział w bieżącym zarządzaniu nią). Peryferyjni członkowie są z firmą związani, ale nie tak blisko. Ostatnia odpowiedzialność drugiego poziomu to odpowiedzialność przed zewnętrznymi grupami. Celem drugiego poziomu odpowiedzialności jest doskonalenie efektów specyficznej działalności firmy w odniesieniu do jej interesariuszy (stakeholders). Szczególną uwagę należy na tym poziomie zwrócić na menedżerów i zaoferowanie im rozsądnych warunków zatrudnienia (bezpieczeństwo ich i ich rodzin).

\section{Rysunek 3 | Struktura drugiego poziomu odpowiedzialności firmy}

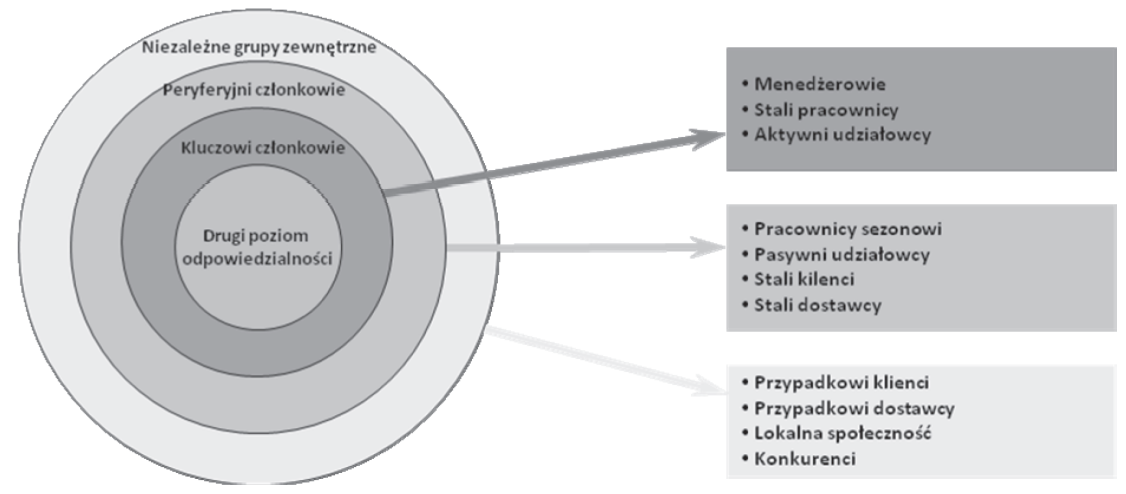

Źródło: opracowanie własne na podstawie Mele (2009: 326-332); materiały do wykładu prof. J. Fontrodona Business Ethics, III edycja AMP Warsaw IESE Business School. 
Wreszcie odpowiedzialność trzeciego poziomu nie jest bezpośrednio związania ze specyficzną aktywnością firmy, ale możliwością zapobiegania erozji dobra wspólnego we współpracy z innymi grupami społecznymi. Firma zachowuje się jak „dobry obywatel”. Zawsze są jakieś problemy społeczne, które wymagają zaangażowania firmy. Ta z kolei może nieść bardzo wartościową pomoc - zatrudnianie niepełnosprawnych, wzmacnianie wartości rodzinnych, promowanie praw kobiet, walka z dyskryminacją, integrowanie z firmą emigrantów-pracowników lub innych dyskryminowanych grup, np. więźniów, wspieranie uniwersytetów i instytutów badawczych, dzielenie się swoją wiedzą biznesową w postaci wykładów, udziału w konferencjach, warsztatach oraz wiedzą na temat doskonalenia środowiska społecznego, by pokazać innym dobre praktyki.

Koncepcja odpowiedzialności firmy nie może pozostać w sferze idei luźno przekazywanej wewnątrz firmy. Musi zostać przekuta na politykę, procesy i procedury, które będą stanowić punkt odniesienia dla decyzji podejmowanych w codziennej działalności. Tak wyrabiane są dobre nawyki postępowania, a ich trwałość buduje wiarygodność firmy. Ta z kolei jest podwaliną ciągłości funkcjonowania firmy. Koncepcja Współtworzonej Wartości Shared Value (Porter, Kramer 2011: 62-77) jeszcze mocniej akcentuje znaczenie odpowiedzialności biznesu. Shared Value to taka polityka firmy i praktyki biznesowe, które wzmacniają konkurencyjność firmy przy jednoczesnej poprawie warunków społecznych i ekonomicznych życia obywateli we wspólnocie lokalnej, w której firma funkcjonuje. Zakłada kreowanie ekonomicznej wartości przez kreowanie społecznej wartości (co jest dobre dla społeczności, jest też dobre dla biznesu). Autorzy stwierdzają, że zysk zyskowi nie jest równy. Zysk wypracowany zgodnie z ideą shared value umożliwia społeczności szybszy rozwój, a firmom szybszy wzrost. Trzeba jednak zachować zdrowy rozsądek pomiędzy unikaniem odpowiedzialności a obarczaniem firmy hiperodpowiedzialnością (Fontrodona 2007: 16-21).

\section{| Odpowiedzialność biznesu - przegląd wyników badań}

Obszar odpowiedzialności przedsiębiorstw, znajdujący się w ostatnich latach w świetle reflektorów szczególnie w krajach wysoko rozwiniętych, jest systematycznie analizowany zarówno przez akademików, jak i praktyków w różnych ujęciach, z punktu widzenia różnych grup interesu. Przeprowadzone dotychczas badania można zakwalifikować do trzech grup/typów:

1) analiza postrzegania odpowiedzialności przez pracowników, zarządzających spółką - analiza kosztów/korzyści z implementacji działań z obszaru społecznej odpowiedzialności, podejmowania decyzji dotyczących działalności przedsiębiorstwa w sposób odpowiedzialny;

2) badania związane z postrzeganiem odpowiedzialności przedsiębiorstw przez dwie podstawowe grupy interesariuszy, od których bezpośrednio zależy działalność podmiotu: inwestorów i konsumentów/klientów oraz

3) analiza zaangażowania przedsiębiorstwa w poszczególne obszary społecznej odpowiedzialności (CSR), która jest dokonywana najczęściej w oparciu o informacje publikowane za pomocą raportów społecznej odpowiedzialności. 
Jeśli chodzi o pierwszy obszar, prowadzone badania mają w większości charakter praktyczny - analizują podejście i opinie zarządzających, którzy podejmują decyzje strategiczne, operacyjne, a przez to wpływają bezpośrednio na „odpowiedzialność przedsiębiorstwa”. I tak, badania prowadzone przez Chartered Institute of Management Accountants i Institute of Business Ethics na próbie 1300 menedżerów z Europy Zachodniej pokazały, że większość z nich (84\% respondentów) uznaje odpowiedzialny biznes za ważny obszar zarządzania strategicznego w firmie, jednak tylko 30\% z nich stosuje te zasady w praktyce (Managing Resposible Business 2008). Badania pokazują również, że 68\% firm uważa, że kwestie ekologiczne będą miały coraz większy wpływ na zachowania nabywcze konsumentów, a w 79\% badanych firm podejmuje się działania mające na celu zmniejszanie ich negatywnego wpływu na środowisko naturalne (np. recycling czy zmniejszenie zużycia energii). Działania z obszaru CSR stanowią doskonałe narzędzie poszukiwania nowych źródeł zysku oraz umożliwiają osiągnięcie przewagi konkurencyjnej. Potwierdziły to badania przeprowadzone przez IBM Institute for Business Value, wśród ponad 250 menedżerów z całego świata, z których $68 \%$ potwierdza tezę postawioną w poprzednim zdaniu. Ponad połowa badanych (54\%) wierzy, iż działania CSR gwarantują im osiągnięcie przewagi nad konkurencją, np. poprzez możliwość pozycjonowania produktów i usług w zupełnie nowy sposób (Kuraszko 2009). Co więcej, dzięki realizacji zasad idei społecznej odpowiedzialności zwiększa się zaufanie do podmiotu gospodarczego. Analizy międzynarodowej firmy analitycznej The Reputation Institute wskazują, że w poszczególnych krajach 50-80\% badanych widzi silny zawiązek zaangażowania przedsiębiorstwa w działania CSR z jego reputacją. Efektywne wdrażanie CSR wymaga tego, by koncepcja ta stała się integralną częścią długofalowej strategii firmy. Realizacja takiego podejścia pozwala przedsiębiorstwu zwiększać stabilność przepływów pieniężnych z działalności operacyjnej w wyniku utrzymania wysokiego standardu w relacjach z klientami i dostawcami oraz silnych związków ze społecznością lokalną. Przekłada się to na wyniki finansowe firm oraz pozycję konkurencyjną i zwiększa umiejętność i elastyczność zarządzania w sytuacjach kryzysowych. Korzyści zaangażowania społecznego potwierdziły np. badania opinii 200 liderów biznesu z ponad 50 krajów, przeprowadzone przez organizację GlobeScan (A GlobeScan Survey 2002). Podobne wyniki zaprezentowali twórcy cyklicznego badania implementacji i komunikowania społecznej odpowiedzialności przedsiębiorstw KPMG International (tabela 1). 
Tabela 1 | Powody implementacji i komunikowania społecznej odpowiedzialności w opinii zarządzających, w grupie 250 największych korporacji świata

\begin{tabular}{|l|c|c|}
\hline \multicolumn{1}{|c|}{ Powody raportowania SOP } & 2008 & 2005 \\
\hline Względy etyczne & $69 \%$ & $53 \%$ \\
\hline Względy ekonomiczne & $68 \%$ & $74 \%$ \\
\hline Reputacja marki & $55 \%$ & $27 \%$ \\
\hline Innowacyjność, uczenie się & $55 \%$ & $53 \%$ \\
\hline Motywowanie pracowników & $52 \%$ & $47 \%$ \\
\hline Zarządzanie, redukcja ryzyka & $35 \%$ & $47 \%$ \\
\hline Wzmacnianie relacjiz dostawcami & $32 \%$ & $13 \%$ \\
\hline Dostęp do kapitału, zwiększanie wartości dla akcjonariuszy & $29 \%$ & $39 \%$ \\
\hline Udział w rynku, pozycja konkurencyjna & $22 \%$ & $21 \%$ \\
\hline
\end{tabular}

Źródło: opracowanie własne na podstawie danych KPMG International Survey of Corporate Responsibility Reporting 2008, KPMG International, Amstelveen, październik 2008.

W ramach drugiego obszaru badawczego analizowana jest odpowiedzialność przedsiębiorstw przede wszystkim w kontekście zapewniania spółce dostępu do kapitału, decyzji inwestycyjnych uczestników rynków finansowych oraz coraz popularniejszych indeksów giełdowych spółek odpowiedzialnych. Ważną rolę odgrywa tu pojęcie socially responsible investing (SRI), czyli strategia inwestowania, ukierunkowana na jednoczesne maksymalizowanie stopy zwrotu z zainwestowanego kapitału (zysków finansowych) i „dobra społecznego” (społecznych i ekologicznych przekonań i oczekiwań). Odpowiedzialność rozpatruje się zatem z dwóch stron - odpowiedzialność inwestora podejmującego decyzje o kierunku zaangażowania kapitału oraz odpowiedzialność podmiotu gospodarczego, w którego walory kapitał jest inwestowany. W ostatnich latach badania empiryczne środowiska akademickiego skupiły się głównie na efekcie, jaki wywarły ujawniane przez spółki informacje odpowiedzialności ich działań na decyzje inwestorów indywidualnych, instytucji finansowych. Część badań sprawdzała ogólną reakcję rynku, czyli kształtowanie się cen akcji, ocenę ryzyka itd. w relacji do raportowania odpowiedzialności spółek (Mathews 1994). Inne badania, przeprowadzone metodą eksperymentu przez dwójkę badaczy (Milne i Chan), oceniały zachowania analityków finansowych (analityków zajmujących się inwestycjami oraz księgowych) podczas procesu decyzyjnego alokowania funduszy inwestycyjnych, którym zaprezentowano pakiety informacji o przedsiębiorstwach z oraz bez dobrowolnych ujawnień dotyczących relacji ze społeczeństwem (Chan, Milne 1999: 265-279; Chan, Milne 1999: 439-457). Wyniki pokazały, że dobrowolne ujawnienia nie wywarły żadnego wpływu na decyzje dotyczące inwestycji krótkookresowych, ale często zaważyły na długookresowej strategii inwestowania. Firmy postrzegane jako odpowiedzialne mogą być zatem doceniane np. przez zwiększone zaufanie inwestorów (lepszy dostęp do kapitału) (por. Roszkowska 2009: 393-418), ponieważ 86\% inwestorów instytucjonalnych w Europie wierzy, że zarządzanie ryzykiem spo- 
łecznym i środowiskowym będzie miało długookresowe konsekwencje dla wartości rynkowej firmy (Bevan et al. 2004: 8), a 74\% Amerykanów twierdzi, że praktyki i zachowania etyczne firm mają bezpośrednie przełożenie na chęć zakupu ich akcji (Key to Building Reputation 2004: 2). Raport Goldman Sachs pt. Green is Gold w którym wykazano, że spółki będące liderami społecznej odpowiedzialności mają lepsze wyniki giełdowe średnio aż o 25\% (Green is Gold 2007), zdaje się potwierdzać tę tezę. Dodatkowo, wychodząc od strony komunikowania działań z obszaru odpowiedzialności, Pleon - największa europejska firma doradcza w zakresie komunikowania - w 2005 r. opublikowała raport, w którym autorzy na podstawie badań empirycznych wykazali, że większość inwestorów, analityków finansowych i agencji ratingowych uważa informacje z obszaru odpowiedzialności spółki za użyteczne w ich pracy zawodowej (Accounting for Good 2005). Zwiększanie atrakcyjności w dostępie do nowych źródeł kapitału widać m.in. w tworzeniu kolejnych indeksów giełdowych, obejmujących społecznie odpowiedzialne przedsiębiorstwa, np. nowojorski Dow Jones Sustainability Index czy warszawski RESPECT Indeks. Metodologia tworzenia indeksów opiera się na wyselekcjonowaniu spółek oferujących tradycyjne produkty i usługi, które uwzględniają w działaniach i strategii zarządzania zasady społecznej odpowiedzialności. Odpowiedzialność okazuje się na tyle ważna, że według szacunków Eurosifu z 2009 roku wartość rynku SRI to 5 bilionów euro. Natomiast jeśli chodzi o grupę klientów, istnieje wiele badań (m.in. prowadzone przez National Geographic Society, GlobScan, Synovate i Aegis, BBC Word, czy European Commission) potwierdzających, że konsumenci w różnych krajach stają się bardziej świadomi i chętni do podejmowania działań w zakresie ochrony środowiska (por. Roszkowska 2010: 365-378): 96\% Europejczyków, twierdzi, iż ochrona środowiska jest dla nich osobiście ważna oraz bardzo ważna (Attitudes of European Citizens 2008). Według badań Euro RSCG The New consumer in the era of mindful spending z 2010 roku, 54\% konsumentów zwraca uwagę na skutki, jakie kupowane przez nich produkty mogą mieć dla społeczeństwa oraz środowiska. Podobne wyniki uzyskano w badaniach polskiego rynku - według analiz Interaktywnego Instytutu Badawczego Polska Zielona Sieć z 2010 roku, ponad 50\% polskich internautów byłoby w stanie zapłacić więcej za kupowane produkty, gdyby mieli świadomość, iż zostały one wyprodukowane w sposób odpowiedzialny.

Ostatnim, trzecim obszarem badawczym jest analiza zaangażowania przedsiębiorstwa w poszczególne obszary odpowiedzialności, dokonywana najczęściej w oparciu o informacje publikowane za pomocą raportów społecznej odpowiedzialności (Roszkowska 2011: 42). W ten typ badań zaangażowane są przede wszystkim środowiska biznesowe, firmy doradcze, które chcą poznać dobre praktyki w obszarze (społecznej) odpowiedzialności, a następnie inkorporować je u swoich klientów. Beneficjentami takich analiz są także wszyscy zarządzający, którzy poznawszy praktyki swoich konkurentów, przedsiębiorstw z innych branż, regionów, w przedsiębiorstwie, którym kierują implementują nowe zasady i zaczynają stosować nowe sposoby zarządzania. Badania obejmujące ten rodzaj zaangażowania w społeczną odpowiedzialność przedsiębiorstw są prowadzone przez wiele instytucji, często w regularnych interwałach czasowych. Badania o najdłuższej tradycji na rynku polskim to z pewnością analiza dobrych praktyk w poszczególnych obszarach odpowiedzialności przedsiębiorstw działających w Polsce, dokonywana dorocznie przez Forum Odpowiedzialnego Biznesu. Raporty Odpowiedzialny biznes 20XX. Dobre Praktyki, będące pod- 
sumowaniem zaangażowania firm w realizację zasad odpowiedzialnego biznesu oraz przeglądem innych inicjatyw związanym z CSR w danym roku, przygotowywane są od ośmiu lat. Inny typ analizy proponują pracownicy KPMG i Universiteit van Amsterdam - co 2-3 lata analizują rodzaje podejmowanych działań z obszaru odpowiedzialność przedsiębiorstw z całego świata na podstawie ujawnianych przezeń w postaci raportów społecznej odpowiedzialności informacji. Wyniki badań skompilowane w raportach KPMG International Survey of Corporate Responsibility Reporting 20XX pozwalają dowiedzieć się m.in., w jakim zakresie spółki implementują społeczną odpowiedzialność, czy odpowiedzialność jest „stosowana wybiórczo”, czy też towarzyszy temu tworzenie i realizowanie strategii, na ile odpowiedzialność jest kwestią zasad, a na ile zabiegów marketingowych (zob. KPMG International Survey 2008). Poza badaniami na skalę globalną istnieje duża liczba analiz krajowych, pokrywających ograniczony zakres tematyczny, przeprowadzonych na ograniczonej liczbie przedsiębiorstw, które pokazują, jakie praktyki w obszarze odpowiedzialności stosowane są w szeroko pojętym biznesie.

Przestawione badania z pewnością dają pewien obraz, co w obszarze społecznej odpowiedzialności robią przedsiębiorstwa, na co zwracają szczególną uwagę, co jest „statystycznie” ważne. Wydaje się, że ten sposób analizy obarczony jest pewnymi zasadniczymi wadami. W sytuacji, kiedy analizujemy odpowiedzialność na podstawie komunikowanych informacji, nie zawsze nasze wnioskowanie będzie poprawne - nie zawsze można interpretować treści raportów społecznej odpowiedzialności jako stan w stu procentach odpowiadający rzeczywistości. (Przedsiębiorstwa mogą podawać nierzetelne informacje, traktując raport jako narzędzie marketingowe, PR-owskie, lub też po prostu omijać kwestie newralgiczne, niewygodne). Ponadto, jeśli oceniać odpowiedzialność na podstawie opinii kadry zarządzającej - wnioski będą wybiórcze i zbyt optymistyczne. I wreszcie, analizy typu case study pozwalają przyjrzeć się szczegółowo odpowiedzialności pojedynczych podmiotów, nie dają jednak możliwości prostej ekstrapolacji wniosków.

Zaprezentowane podejścia badawcze i typy prowadzonych badań nie są sprzeczne z przyjętą w opracowaniu koncepcją odpowiedzialności biznesu. Problem jedynie w tym, że wyjaśniają ją w pewnych punktach „współśrodkowych kręgów”, ale bez wyjaśniania spójności całej koncepcji odpowiedzialności. Brakuje w nich też odniesienia dla celu nadrzędnego, z którego wynika porządek poziomów odpowiedzialności. Pewnie dlatego koncepcja społecznej odpowiedzialności przechodzi swoje kolejne wcielenia.

\section{Odpowiedzialność biznesu w praktyce - wyniki badań i wnioski z projektu Czas na rozwój. Człowiek i biznes w społeczeństwie obywatelskim}

W panelu Odpowiedzialność biznesu w kreowaniu dobrobytu gospodarczego i społecznego wzięło udział ponad 10 osób reprezentujących różne środowiska: właścicieli firm (przedsiębiorców), pracowników, władze lokalne, uczelnie wyższe. Celem dyskusji było zdefiniowanie odpowiedzialności biznesu i jej poziomów. W trakcie rozmowy poszukiwaliśmy odpowiedzi na następujące pytania: 
1. Co to znaczy odpowiedzialność biznesu? Za co biznes jest odpowiedzialny?

2. Czy współczesny biznes rozwija się kosztem społeczeństwa?

3. Z czego wynika kryzys zaufania do biznesu?

4. Czy efektywność biznesu stoi w opozycji do rozwoju społecznego?

5. Z czym wiąże się dla biznesu i społeczeństwa utożsamianie rynku ze społecznością, a klienta z obywatelem?

6. W jaki sposób potrzeby społeczeństwa definiują rynek?

7. Czy społeczną odpowiedzialnością biznesu jest kreować zysk?

8. Czy istnieje i jest możliwy do osiągnięcia „zdrowy poziom zysku”?

9. Czy to, co jest dobre dla biznesu, jest też dobre dla społeczeństwa?

Ze względu na krótki czas nie udało się w pełni wyczerpać tematu, jednak aktywność uczestników i zaangażowanie w temat pozwalają wnioskować, że konieczne jest jego dalsze zgłębianie.

Podstawowe pytanie, na które uczestnicy panelu poszukiwali odpowiedzi, brzmiało: „Co przede wszystkim powinna robić firma, aby można było o niej powiedzieć, że jest to firma odpowiedzialna?". Według uczestników - przede wszystkim powinna wypełniać swoje zasadnicze obowiązki. Głównym zadaniem przedsiębiorstwa jest dostarczanie towarów i usług przydatnych dla ludności oraz generowanie wartości dodanej i dzielenie tego nowego dobrobytu wśród swych akcjonariuszy, pracowników, społeczności, w której firma się rozwija, a także kapitalizowanie firmy, by zagwarantować własną przyszłość. Towary i usługi dostarczane przez firmę muszą spełniać kryterium wysokiej jakości i odpowiedniej ceny, a także muszą być przydatne dla ludności. Społecznie odpowiedzialna firma nie może realizować swojej działalności, bazując na ludzkich słabościach. Generowanie wartości dodanej oznacza jej etyczne zdobywanie bez wchodzenia w układy monopolistyczne lub korzystania ze specjalnych przywilejów. Firma jest główną instytucją redystrybucji bogactwa i dzieli to bogactwo między swoich interesariuszy w odpowiednich formach:

- akcjonariuszy - w formie dywidend,

- pracowników - w formie tradycyjnych wynagrodzeń, szkoleń i dodatków specjalnych (różne formy pomocy, np. pożyczki na zakup mieszkania, pomoc na wychowanie dzieci, na lepszy system opieki medycznej itd.)

- społeczność - poprzez płacenie podatków.

Równolegle firma musi zapewnić sobie i swoim właścicielom przyszłość, inwestując w nowe technologie i aktywa. Bez tego nie jest w stanie zagwarantować sobie rozwoju i przetrwania, skazując się na bankructwo. Dopiero kiedy firma spełni wszystkie swoje podstawowe obowiązki, możemy powiedzieć, że środki, które przeznacza na cele społeczne, są „,prawdziwe”, a nie „wykradzione" klientom, pracownikom, dostawcom, społeczeństwu lub przyszłym pokoleniom (wynik braku przewidywania przyszłości). Nie można dyskutować o odpowiedzialności firmy, jeśli nie spełnia ona swoich zasadniczych obowiązków. Jeśli tak nie jest, to informowanie o podejmowa- 
nych działaniach na rzecz społecznej odpowiedzialności biznesu można traktować jedynie jako działania marketingowe skierowane na społeczne wyróżnienie się właścicieli.

Kwestia odpowiedzialności przedsiębiorstw dyskutowana była w kontekście uwarunkowań gospodarczych globalnych i krajowych oraz uwarunkowań kulturowych. Poniżej przedstawiono kluczowe wnioski, jakie zostały sformułowane w tej części dyskusji:

1. Podejście przedsiębiorstw do odpowiedzialności zmieniało się $\mathrm{w}$ długotrwałym procesie związanym z transformacją ustrojowo-gospodarczą. Na jej początku panowało podejście eksploatacyjne typu - pierwszy klient, pierwsza sprzedaż, szybki zysk; brak odpowiedzialności. Obecnie następuje zmiana w kierunku przyjmowania przez biznes coraz szerszego zakresu odpowiedzialności.

2. Kluczowe w koncepcji odpowiedzialności biznesu jest zaufanie na każdym poziomie - zarówno społeczeństwa do przedsiębiorstw, jak i przedsiębiorstw do działania struktury instytucjonalnej państwa.

3. Słabość instytucji państwa (głównie rynku pracy i opieki socjalnej), niewyjaśnione sprawy własnościowe, opieszałość sądów to tylko niektóre z czynników, które wpływają na zmniejszenie zaufania do przedsiębiorstw i poczucie obarczania ich hiperodpowiedzialnością za rozwiązywanie problemów społecznych.

4. Jako przykład modelu wzmacniającego zaufanie w gospodarce podano Niemcy i społeczną gospodarkę rynkową, gdzie wolny rynek jest nadrzędny, a jego uczestnicy i instytucje są odpowiedzialne za kreowanie realnej, a nie wirtualnej wartości. Stąd istotna rola regulatora - w przypadku Unii Europejskiej na poziomie ponadnarodowym.

5. Na poziomie lokalnym nie zauważa się dużego spadku zaufania do przedsiębiorstw, jednak w przypadku firm globalnych można mówić o zdecydowanym kryzysie zaufania. Wynika to z dużej mobilności korporacji, braku odpowiedzialności za społeczność lokalną. Kryzys zaufania wzmógł się od $2008 \mathrm{r}$. w wyniku globalnego zjawiska oderwania systemu finansowego od realnej gospodarki. Spekulacje rynkowe, np. na rynku energetycznym, także podważają zaufanie do biznesu.

6. Na poziomie regionalnym mamy do czynienia z przypadkami wchodzenia na rynek przedsiębiorstw niezwiązanych z regionem i ich niszczycielskiego, eksploatacyjnego podejścia nastawionego na krótkotrwały efekt ekonomiczny.

7. Wiele firm docenia jednak lokalny potencjał społeczny. Z jednej strony rozpoznają zasoby w regionie, w którym funkcjonują i starają się je wykorzystać, a z drugiej wnoszą wartość dodaną do społeczeństwa.

8. Rozwija się także współpraca lokalnych firm z uczelniami. Ponadto zaniedbania na poziomie szkolnictwa zawodowego mogą być polem do działań dla firm, bo jego efekty mają realny wpływ na podstawową działalność przedsiębiorstw.

Powyższe wnioski umożliwiły sformułowanie opinii, dotyczącej tego, że w praktyce działania przedsiębiorstw można mówić o dwóch płaszczyznach odpowiedzialności firmy. Pierwsza 
to obowiązek - prowadzenie firmy zgodnie z regulacjami prawnymi, a druga to świadomość wyższego zakresu odpowiedzialności, m.in. za edukację, środowisko, kulturę, tradycję. Dodać należy, że porównanie wyników spółek giełdowych deklarujących prowadzenie odpowiedzialnego biznesu ze spółkami, które tego nie deklarują, nie wskazuje, aby te pierwsze miały lepsze notowania. Rodzi się tu pytanie, dlaczego społecznie odpowiedzialne oświadczenia nie są promowane i czy to właśnie nie jest również objaw braku zaufania do firm. Deklaracje o prowadzeniu społecznie odpowiedzialnego biznesu mogą nie być wiarygodne i traktowane jako zamierzone działania PR-owe.

W trakcie trwania konferencji przeprowadzone zostało również badanie ankietowe, które niesie ze sobą kolejne wnioski. W badaniu wzięło udział 32 uczestników, w wieku od poniżej 30 do powyżej 50 lat. Uczestnicy reprezentowali różne środowiska i zawody: od specjalistów, przez naukowców, po właścicieli firm. Określając obszar, za który biznes powinien być odpowiedzialny, wskazywali oni przede wszystkim na: pracowników, klientów, generowanie wartości dodanej w społeczeństwie i gospodarce, własny rozwój, społeczność lokalną, środowisko, kulturę. Wskazując na hierarchię ważności obszarów odpowiedzialności menedżera/właściciela, respondenci podkreślali, że najważniejsza jest odpowiedzialność za samą firmę, a w drugiej kolejności na rodzinę. Najmniej istotne obszary według respondentów to społeczeństwo i sama osoba menedżera/właściciela. Ankietowanym trudno było się wypowiedzieć, czy rządy i społeczeństwo próbują przerzucić na biznes wydatki związane z rozwiązaniem problemów społecznych (35\% odpowiedzi): 29\% odpowiedzi wskazywało, że raczej nie, a 19\% tak i 16\% raczej tak. Zdecydowana większość (58\% odpowiedzi „tak” i 32\% odpowiedzi „raczej tak”) wskazała, że kreowanie ekonomicznej wartości poprzez kreowanie społecznej wartości jest dobre i dla biznesu, i dla społeczeństwa. Wyniki ankiety potwierdziły wnioski z dyskusji, że aby można było mówić o społecznej odpowiedzialności biznesu, musi być spełniony warunek dotyczący wypełniania przez firmę jej zasadniczych obowiązków.

\section{| Zakończenie}

Tylko biznes może kreować dobrobyt gospodarczy, ale firmy w coraz większym stopniu są postrzegane jako podmioty żyjące na koszt społeczeństwa. Ponadto coraz wyraźniej są one obwiniane za kluczowe problemy społeczne, środowiskowe i ekonomiczne. Rządy i społeczeństwo próbują przerzucić na biznes wydatki związane z rozwiązaniem problemów społecznych, a pomimo lawinowego wzrostu praktyk w zakresie społecznej odpowiedzialności biznesu zaufanie obywateli do niego jest nadwyrężone. Poszukiwanie shared value reprezentuje następny stopień w ewolucji kapitalizmu i gospodarki rynkowej. Troska o sprawy społeczne będzie wyróżniającą charakterystyką strategii firm ery po kryzysie finansowym 2008 r. Inkorporowanie kwestii społecznych i obywatelskich do strategii i praktyki biznesowej firm jest przełomem w myśleniu menedżerskim.

Mówiąc zatem o społecznej odpowiedzialności firmy, mamy na myśli pewne minimum działań, a mówiąc o etyce biznesu - maksimum. Pytanie: Czy mogę zrobić więcej? zamieńmy raczej na pytanie: Czy wolno mi zrobić mniej? 


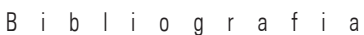

Accounting for Good: the Global Stakeholder Report (2005) Amsterdam/Bonn: Pleon.

A GlobeScan Survey of Business Leaders on Sustainable Development - Highlight Report (2002) Toronto: GlobeScan Inc.

Bevan S., Isles N., Emery P., Hoskins T. (2004) Achieving High Performance: CSR at the Heart of Business. The Work Foundation.

Caroll A.B. (2008) A history of corporate social responsibility: concepts and practices. Crane W.A., McWilliams A., Matten D., Moon J., Siegel D.S. (red.), Corporate Social Responsibility. Oxford: Oxford University Press.

Chan C., Milne M. (1999) Investor Reactions to Corporate Environmental Saints and Sinners: An Experimental Analysis. Accounting and Business Research, Vol. 29.

European Commission, Directorate General Environment/ Eurobarometer 295, Attitudes of European Citizens towards the Environment (2008) marzec.

Fontrodona J. (2007) Where is my company going?, IESE Alumni Magazine, January-March.

Fontrodona J. (2006) Turning Words into Action. IESE Alumni Magazine, January-March.

Green is Gold (2007) Goldman Sachs Group Inc., 22 czerwca.

Key to Building Reputation and Retaining Trust (2004) The Wirthlin Report, kwiecień.

KPMG International Survey of Corporate Responsibility Reporting 2008 (2008) KPMG International, Amstelveen, październik.

Managing Responsible Business (2008) Chartered Institute of Management Accountants, Institute of Business Ethics. London: CIMA.

Mathews M.R. (1994) Socially Responsible Accounting. London: Chapman \& Hall.

Mele D. (2009) Business Ethics in Action. Seeking Human Excellence in Organizations. New York: Palgrave Macmillan.
Milne M., Chan C. (1999) Narrative Corporate Social Disclosures: How Much of a Difference do the Make to Investor Decision-Making. British Accounting Review, No. 31.

Minor D.B. (2010) Corporate Social Responsibility as Reputation Insurance: Theory and Evidence. Haas School of Business, UC Berkeley, July.

Porter M.E., Kramer M.R. (2011) The Big Idea: Creating Shared Value. Harvard Business Review, January.

Roszkowska P. (2011) Rewolucja w raportowaniu biznesowym. Interesariusze, konkurencyjność, społeczna odpowiedzialność. Warszawa: Difin.

Roszkowska P. (2010) Raporty społecznej odpowiedzialności w budowie relacji z klientem. W: Dobiegała-Korona B., Doligalski T. (red.), Zarzqdzanie wartościq klienta. Pomiar i strategie. Warszawa: Poltext.

Roszkowska P. (2009) Raportowanie społecznej odpowiedzialności biznesu. W: Szablewski A. (red.), Migracja kapitału w globalnej gospodarce. Warszawa: Difin.

Sysko-Romańczuk S. (2011) Zarządzanie przez wartości. Człowiek i jego rozwój w centrum działań polityki, przedsiębiorczości, etc. W: Dardziński P., Longchamps de Berier F., Szczucki K. (red.), Prawo naturalne - Natura prawa. Warszawa: Wydawnictwo C.H. Beck, s. 187-196.

Sysko-Romańczuk S. (2007) Przedsiębiorstwo i konkurencja w tworzeniu dobra wspólnego - teoria i praktyka zarządzania. Przegląd Organizacji, nr 3.

Sysko-Romańczuk S., Kruszyńska A. (2009) Dobro Wspólne. Przedsiębiorstwo Przyszłości, nr 1.

Wood D.J., Logsdon J.M. (2002) Business Citizenship: From Individuals to Organizations. W: Freeman R.E., Venkatraman S. (red), Ethics and Entrepreneurship, Ruffin Series, No. 2, Special Issue of Business Ethics Quarterly.

Valero A., y Lucas J.L. (1999) Política de Empresa. Pamplona: Eunsa. 